\title{
Regional diversity of the Setouchi Volcanic Rocks, Miocene SW Japan
}

HIRONAO SHINJOE ${ }^{1}$, YUJI ORIHASHI ${ }^{2}$

${ }^{1}$ Center for General Educaton, Tokyo Keizai University

(shinjoe@tku.ac.jp)

${ }^{2}$ Department of Earth and Environmental Sciences, Faculty of Science and Technology, Hirosaki University

(oripachi@hirosaki-u.ac.jp)

Middle Miocene trench proximal magmatism took place in more than $80 \mathrm{~km}$ trenchward region of the Quarternery volcanic front in the SW Japan arc. The Outer Zone granitic rocks which are distributed to the south of the Median Tectonic Line (MTL) are the most voluminous member of the magmatism ocurred ranging from 15.5 to $13.5 \mathrm{Ma}$ [1]. To the north of the MTL, are distributed Setouchi Volcanic Rocks (SVR), which are mainly comprised of medium-K andesites and basalts, high- $\mathrm{Mg}$ andesites, and garnet-dearing dacites and rhyolites. The magmatism are usually ascribed to the subduction of young hence hot Shikoku Basin lithospere of the Philippine Sea plate (PHS), as the trench proximal magmatism ocurred just after the clockwise roation of the SW Japan arc and commencement of the subduction of the Shikoku Basin. The peculiar rock types of the Setouchi Volcanic Rocks are high-Mg andesite and adakitic daciterhyolite; adakitic dacite-rhyolite with high $\mathrm{K}_{2} \mathrm{O}$ content were suggested to be formed by melting of sediments on the subducted slab at mantle depth, and high-Mg andesite magma has been considered to be derived from the reaction of slab melt with mantle wedge peridotite [2][3]. We review the radiometric age and whole rock chemistry data of the SVR including the those of our own to clarify the regional diversity of the Setouchi magmatism. In particular, we paid attention to the time and space distribution of the high-Mg andesite and adakitic dacite-rhyolite to discuss the possibility of the spatial extent of the magmatism affected by the slab melting of the Shikoku Basin of the PHS, reached ca. $700 \mathrm{~km}$ along arc direction.

[1]Shinjoe, Orihashi \&Anma (2019) Geol.Mag., doi: 10.1017/S0016756819000785 [2]Tatsumi (2006) Annual Rev.Earth Planet. Sci.34, 467. [3] Shimoda \& Tatsumi (1999) Island Arc, 8, 383. 